\title{
Addressing Impact Evaluation Gaps in Belt and Road Initiative Projects in Africa: The Standard Gauge Railway Project in Kenya as a Proof of Concept
}

\author{
Keren Zhu \\ Doctoral Fellow; Pardee RAND Graduate School, 1776 Main Street, \\ Santa Monica, CA 90401-3208, USA \\ kzhu@prgs.edu \\ Rafiq Dossani \\ Director; Center for Asia Pacific Policy, RAND Corporation, 1776 Main Street, \\ Santa Monica, CA 90401-3208, USA \\ rdossani@rand.org \\ Jennifer Bouey \\ Tang Chair for China Policy; Center for Asia Pacific Policy, RAND \\ Corporation, 1776 Main Street, Santa Monica, CA 90401-3208, USA \\ jbouey@rand.org
}

\begin{abstract}
The impact of the Belt and Road Initiative (BRI) to global development will be unprecedented and significant, and developmental impact evaluation is therefore central to understanding BRI projects and making informed decisions. Compared with evaluations of individual projects and programs, evaluation of large and mega infrastructure projects under the BRI is particularly challenging and complex in integrating stakeholder objectives, accounting for social benefit and costs, and tracking long-term project impact. In this paper, we summarize the key drawbacks of existing BRI evaluation frameworks, propose a systematic evaluation framework elicitation method based on the inputs from BRI subject matter experts and verified through stakeholder participation, and apply an interim evaluation framework in understanding the Mombasa-Nairobi Standard Gauge Railway project in Kenya, as a proof of concept of a comprehensive evaluation framework. In doing so, we seek to provide a tool for BRI
\end{abstract}


decision makers and stakeholders to assess these projects holistically at planning, construction and operation stages.

\section{Keywords}

Belt and Road Initiative - program evaluation - evaluation framework - Standard Gauge Railway - Kenya

\section{Introduction}

Infrastructure provides services that enable society to function and to thrive, serves as impetus for economic growth and poverty alleviation, and lies at the heart of efforts to meet every country's developmental goals. Insufficient infrastructure investment may have led to inadequate and uneven socio-economic development across the world. In Africa, huge infrastructure gaps remain an obstacle for growth. The African Development Bank (AfDB) estimates the minimum infrastructure needs for countries to sustain growth of their economies, population, income level and replace ageing infrastructure - at US\$130 bn to US $\$ 170$ bn per annum. More than half of the funding shortage is not met (AfDB, 2011).

In 2013, Chinese President Xi Jinping announced plans for a transcontinental infrastructure initiative. China would work with partner countries under two programs termed the Silk Road Economic Belt and the 21st Century Maritime Silk Road. Together, these have come to be known as the Belt and Road Initiative (BRI). Set to encompass 4.4 billion people with a cumulative GDP of around US\$ 21 trillion, the BRI is being implemented in over 70 developing countries, as exemplified by completed and ongoing projects, such as Mombasa-Nairobi Standard Gauge Railway, power plants from Nigeria to Djibouti, rehabilitation and upgrading project across eight cities in Ethiopia, and Eastern Industrial Park.

The impact of BRI to world development will be unprecedented and significant. According to the World Bank (2019), BRI transport projects could reduce travel times along economic corridors by $12 \%$, increase trade between $2.7 \%$ and $9.7 \%$, increase income by up to $3.4 \%$ and lift 7.6 million people from extreme poverty. At the same time, BRI projects also presents risks common to many major infrastructure projects: debt risks, corruptions, stranded infrastructure, social and environmental risks. BRI transport projects have the 
potential to substantially improve trade, foreign investment, and living conditions for participating countries - but only if BRI project providers from China and the recipient country governments can work together to adopt policy that can increase transparency, improve sustainability, and mitigate environmental, social and corruption risks. The overarching goal of this paper is to assist the BRI projects and their recipient countries to evaluate these projects through a framework at the design, negotiation, and evaluation phases.

Evaluating the impact of infrastructure megaproject as exemplified by BRI projects is methodologically and practically challenging. Methodologically, it is relatively easy to apply traditional impact evaluation methods such as difference-in-difference or instrumental variable methods on smaller infrastructure projects to compare places with and without service (Dinkelman, 2011; Duflo and Pande, 2007). Yet it is almost impossible to identify counterfactuals for mega projects such as a centenary railway, a large power plant or a major port, because of their unique standing in a country or even a region. In addition to difficulties in counterfactual identification, other methodological challenges include working through a long causal chain of spillover effects and identifying a valid and reliable dataset, which explain lack of empirical research on the outcomes and impact of megaprojects. At a practical level, megaproject evaluation is challenging because of exceptionally large budgets, considerable economic and political interests involved, gigantic temporal and spatial scales, and sharp normative disagreements among stakeholders involved (Lehtonen, Joly, and Aparicio, 2017). In contrast to an abundance of literature about megaproject pathologies, there is sparse literature on megaproject evaluation (Lehtonen, 2014).

So far, the methods that have been proposed for evaluating megaproject impact include comparing more and less affected units, constructing counterfactuals based on similar countries and time series data, applying methods from economic history studies to delve into long causal chains, taking a Bayesian approach once these sorts of studies have been done well for a few countries, conceptualizing and mapping megaproject as an evolving network, evaluating program organization using fuzzy synthetic evaluation method (Duflo and Pande, 2007; Estache, 2010; Dinkelman, 2011; McKenzie, 2011; Hansen et al., 2013; McKenzie, 2010; Lehtonen, 2014; Hu et al., 2015). These methods offer helpful insights at an operational level, but do not provide a systematic framework that guides mega infrastructure evaluation design.

Although evaluation researchers have recognized the importance of a holistic evaluation framework for megaprojects that define success beyond the project close-out stage to account for direct and indirect impacts on organizations, 
national budgets, community, society, and environment (Zidane, Johansen, and Ekambaram, 2015; Fahri et al., 2015), a practical and comprehensive evaluation framework has not been generated.

BRI evaluation framework design confronts challenges that are similar to megaproject evaluation design. Many projects are being undertaken at scales that will generate significant public goods. Commonly-used tools, such as financial cost-benefit analysis will not capture the social benefits such as area development, or potential social costs such as environmental degradation. Project impact take effect at different scales, which makes comprehensive capture of various impact particularly challenging. Stakeholders have different needs and prioritizations for what should be included in an evaluation framework, and consensus building thus presents another challenge for conceiving a BRI evaluation framework.

Given the massive scale of BRI projects, establishing a framework for evaluating BRI projects could be challenging. In conceiving the evaluation frameworks for BRI projects, evaluators should consider the policy objectives of the Initiative as well as regional development goals and global acceptable standards and good practices. A second complexity is that many projects are being undertaken at scales that will generate significant public goods. Commonly-used tools, such as financial cost-benefit analysis will not capture the social benefits such as area development, or potential social costs such as environmental degradation. In addition, project impact take effect at different scales, making capturing various impact comprehensively particularly challenging.

The construction of the evaluation framework for BRI projects should take into account both the policy objectives of the Chinese government and international standards. The stated objectives of the Initiative need to be incorporated. The five pillars of the Belt and Road - policy coordination, facilities connectivity, unimpeded trade, financial integration and people-to-people exchanges (NDRC et al., 2015) - guide China's efforts to connect to its neighbors and to promote trade and China's international influence. The United Nations has led the search for a common wider concept of development, captured first in the Millennium Development Goals and most recently in the Sustainable Development Goals, agreed to by 193 countries. China has committed that the BRI will be aligned with the SDGs through its partnership with the United Nations Development Program (NDRC et al., 2017).

The paper proceeds as follows. We first make a case for the centrality of BRI program evaluation and describe the characteristics and drawbacks of 
existing BRI evaluation frameworks. Then we describe a new methodology for framework elicitation and propose an interim evaluation framework for the BRI projects. Third, we apply the interim framework to a case study, the Nairobi-Mombasa Standard Gauge Railway. Fourth, we derive learnings about the developmental implications of BRI projects for Africa from the case study and discuss how to improve our current framework of analysis.

Program evaluation systematically investigates a program's effectiveness, efficiency and quality, and serves as a timely tool for measuring the success or failure of BRI projects. It helps check on risks and uncertainties in project planning, helps with project implementation, assesses program outcomes and impact and helps avoid resource waste and unintended consequences, to make sure that resources are appropriately used globally.

Evaluation of BRI projects in African faces three major challenges. First, project-level data for BRI projects lacks transparency, while country- and regional-level data collected by national governments have jarring collection cycles and baselines, which makes it extremely difficult to capture data needed for effective evaluation. Second, unprecedented in its scale, BRI projects are more likely to underestimate costs, environmental impacts, and overvalue revenues and economic development, with considerable risks concealed from key stakeholders. This requires evaluation to capture BRI's impact not only at individual project level, but also as a system. Third, there is a tension between the technical rigor required for BRI evaluation and accessibility of the evaluation tools to countries with limited technocratic capacity.

Compared with evaluations of individual projects and programs, evaluation of mega and series of infrastructure projects under the BRI is particularly challenging and complex due to the large number of stakeholders involved, and spillover effects across various impact dimensions, scales and time horizons.

\subsection{Complexity in Integrating Different Stakeholders' Objectives in Evaluation}

Program evaluation is also crucial for a wide range of BRI stakeholders with very different interests, objectives and priorities (Table 1). 
TABLE 1 Multiple stakeholders' objectives and the tools available to assess projects against these objectives

\begin{tabular}{|c|c|c|c|c|c|}
\hline Objectives & $\begin{array}{l}\text { Lending } \\
\text { country }\end{array}$ & $\begin{array}{l}\text { Borrowing } \\
\text { country }\end{array}$ & $\begin{array}{l}\text { Project } \\
\text { manager }\end{array}$ & $\begin{array}{l}\text { Local } \\
\text { community }\end{array}$ & $\begin{array}{l}\text { International } \\
\text { development } \\
\text { agencies/ } \\
\text { local NGOs }\end{array}$ \\
\hline $\begin{array}{l}\text { Trade and } \\
\text { connectivity }\end{array}$ & $\begin{array}{l}\text { Connectivity } \\
\text { and trade } \\
\text { benefit with } \\
\text { the lending } \\
\text { country }\end{array}$ & $\begin{array}{l}\text { Cultivating } \\
\text { comparative } \\
\text { advantage as } \\
\text { regional } \\
\text { trade and } \\
\text { transportation } \\
\text { hub }\end{array}$ & $\begin{array}{l}\text { Ease of trans- } \\
\text { portation of } \\
\text { raw materi- } \\
\text { als and staff } \\
\text { during project } \\
\text { implementa- } \\
\text { tion }\end{array}$ & $\begin{array}{l}\text { Local trade } \\
\text { and transpor- } \\
\text { tation route } \\
\text { development }\end{array}$ & $\begin{array}{l}\text { Not particu- } \\
\text { larly relevant }\end{array}$ \\
\hline $\begin{array}{l}\text { Economic } \\
\text { development }\end{array}$ & $\begin{array}{l}\text { Macro- } \\
\text { economic } \\
\text { performance } \\
\text { indicators } \\
\text { Procurement } \\
\text { of goods } \\
\text { from lending } \\
\text { country }\end{array}$ & $\begin{array}{l}\text { Employment } \\
\text { promotion } \\
\text { Technological } \\
\text { transfer } \\
\text { Local business } \\
\text { development } \\
\text { Local } \\
\text { procurement }\end{array}$ & $\begin{array}{l}\text { Not } \\
\text { particularly } \\
\text { relevant }\end{array}$ & $\begin{array}{l}\text { Employment } \\
\text { promotion } \\
\text { Technological } \\
\text { transfer } \\
\text { Local business } \\
\text { development } \\
\text { Local } \\
\text { procurement } \\
\text { Transforma- } \\
\text { tion of local } \\
\text { industries and } \\
\text { sectors }\end{array}$ & $\begin{array}{l}\text { Equity of } \\
\text { economic } \\
\text { development } \\
\text { Poverty } \\
\text { reduction }\end{array}$ \\
\hline Financial & $\begin{array}{l}\text { Long-term } \\
\text { returns }\end{array}$ & $\begin{array}{l}\text { Debt } \\
\text { repayment } \\
\text { Financial } \\
\text { integration } \\
\text { Project } \\
\text { revenue } \\
\text { Sharing of } \\
\text { equity with } \\
\text { lender }\end{array}$ & $\begin{array}{l}\text { Project budget } \\
\text { and construc- } \\
\text { tion cost }\end{array}$ & $\begin{array}{l}\text { Not particu- } \\
\text { larly relevant }\end{array}$ & $\begin{array}{l}\text { Presence of } \\
\text { "debt trap } \\
\text { diplomacy" } \\
\text { and political } \\
\text { manipulation } \\
\text { via debt }\end{array}$ \\
\hline
\end{tabular}


TABLE 1 Multiple stakeholders' objectives and the tools available to assess projects against these objectives (cont.)

\begin{tabular}{|c|c|c|c|c|c|}
\hline Objectives & $\begin{array}{l}\text { Lending } \\
\text { country }\end{array}$ & $\begin{array}{l}\text { Borrowing } \\
\text { country }\end{array}$ & $\begin{array}{l}\text { Project } \\
\text { manager }\end{array}$ & $\begin{array}{l}\text { Local } \\
\text { community }\end{array}$ & $\begin{array}{l}\text { International } \\
\text { development } \\
\text { agencies/ } \\
\text { local NGos }\end{array}$ \\
\hline Governance & $\begin{array}{l}\text { Policy reforms } \\
\text { Regulatory } \\
\text { reforms } \\
\text { Planning } \\
\text { and project } \\
\text { coordination } \\
\text { Risk } \\
\text { management }\end{array}$ & $\begin{array}{l}\text { Government } \\
\text { agency } \\
\text { coordination } \\
\text { Quality } \\
\text { and time to } \\
\text { complete }\end{array}$ & $\begin{array}{l}\text { Quality } \\
\text { and time to } \\
\text { complete } \\
\text { Coordination } \\
\text { with local } \\
\text { government } \\
\text { Localization of } \\
\text { management } \\
\text { Regulatory } \\
\text { compliance }\end{array}$ & $\begin{array}{l}\text { Not particu- } \\
\text { larly relevant }\end{array}$ & Corruption \\
\hline $\begin{array}{l}\text { Social costs } \\
\text { and benefits }\end{array}$ & $\begin{array}{l}\text { Trade } \\
\text { Connectivity } \\
\text { to wider } \\
\text { networks }\end{array}$ & $\begin{array}{l}\text { Area } \\
\text { development } \\
\text { Employment } \\
\text { Technology } \\
\text { transfer } \\
\text { Trade } \\
\text { Connectivity to } \\
\text { wider networks }\end{array}$ & $\begin{array}{l}\text { Corporate } \\
\text { social } \\
\text { responsibility } \\
\text { Community } \\
\text { resistance } \\
\text { to project } \\
\text { development }\end{array}$ & $\begin{array}{l}\text { Social, environ- } \\
\text { mental, and } \\
\text { health impact } \\
\text { on local } \\
\text { communities }\end{array}$ & $\begin{array}{l}\text { Social, environ- } \\
\text { mental, and } \\
\text { health impact } \\
\text { on local } \\
\text { communities }\end{array}$ \\
\hline
\end{tabular}

SOURCE: THE AUTHOR'S SUMMARY BASED ON LITERATURE REVIEW AND PRACTICAL EXPERIENCE

As the table above shows, different key stakeholders have their own objectives. While some convergence of objectives among various stakeholders, there is significant divergence in other areas. How to leverage the convergence of interests and bridge the divergence is central to a balanced and stakeholderfriendly evaluation design.

\subsection{Complexity of Accounting for Multi-Dimensional Impact, Benefit and Cost Cross Scales}

In accounting for social costs and benefits of BRI projects, an evaluation framework needs to comprehensively address economic development impact assessment, as well as political, social, environmental, health considerations. 
Based on the challenges that have emerged in BRI projects, it is particularly important to delve into the following domains in assessing project impact.

For example, the dimensions and questions listed in Table 2 need to be carefully assessed to comprehensively understand the impact of в RI projects.

TABLE 2 Evaluation dimensions and checklist

\section{Framework items Questions and checklist}

$\begin{array}{ll}\text { Trade and connectivity } & - \text { How does the project reduce travel time and transit } \\ & \text { costs? } \\ - & \text { How has trade volume increased? } \\ - & \text { How was foreign direct investment affected? } \\ \text { Security and geopoliti- } & - \text { Has the project triggered increasing incidence of } \\ \text { cal risks } & \text { regional conflicts, wars and terrorism? } \\ & - \text { Has the project been affiliated with military usage? } \\ & - \text { Was the sovereignty of the country endangered? } \\ \text { Local economic } & - \text { Does the project lead to economic development of the } \\ \text { development } & \text { city/region? } \\ - & \text { How does the project change regional economic } \\ & \text { development dynamics? } \\ - & \text { Does the project promote balanced and inclusive local } \\ & \text { economic development? Who wins and who loses? } \\ - & \text { How committed are the local and national governments } \\ & \text { of the host country to make the project successful? } \\ \text { Project Identity } & - \text { To what extent are local enterprises and small and } \\ \text { Local enterprise/ } & \text { medium enterprises (smes) involved in the } \\ \text { SME engagement } & \text { development of the project? } \\ \text { Local labor inclusion } & - \text { What is the proportion of local labor employed for the } \\ & \text { project? } \\ - & \text { What kind of positions do local labors take in these } \\ & \text { projects? } \\ - & \text { What are the forms of protests and resistance from local } \\ & \text { labor and local population? }\end{array}$


TABLE 2 Evaluation dimensions and checklist (cont.)

\section{Framework items Questions and checklist}

\begin{tabular}{|c|c|}
\hline Technological transfer & $\begin{array}{l}\text { - Has the foreign partner transferred the skills and } \\
\text { technology needed to the local partners for project } \\
\text { operation and maintenance? } \\
\text { - How much vocational training and technical skills } \\
\text { transfer took place? } \\
\text { - Have the local staff acquired skills for the maintenance } \\
\text { of the project? }\end{array}$ \\
\hline $\begin{array}{l}\text { Regulations and } \\
\text { compliance }\end{array}$ & $\begin{array}{l}\text { - How complete and effective are the laws and } \\
\text { regulations that govern corruption, project planning, } \\
\text { feasibility study, implementation and operation phases? }\end{array}$ \\
\hline Financial sustainability & $\begin{array}{l}\text { - How has the financing structure impacted the BRI } \\
\text { recipient country's ability to repay the debt? } \\
\text { - Have the partner countries amicably negotiated } \\
\text { unexpected financial events, such as cost overruns? }\end{array}$ \\
\hline $\begin{array}{l}\text { Environmental } \\
\text { sustainability }\end{array}$ & $\begin{array}{l}\text { - How complete and effective are the laws and } \\
\text { regulations that have environmental impacts? } \\
\text { - How has the project affected the natural and built } \\
\text { environment? } \\
\text { - What types of the pollution has the project generated? }\end{array}$ \\
\hline $\begin{array}{l}\text { Social and community } \\
\text { sustainability }\end{array}$ & $\begin{array}{l}\text { - Are there effective mechanisms in place to ensure local } \\
\text { stakeholders and community engagement before and } \\
\text { after the project? } \\
\text { - How has the project affected the life of local residents? }\end{array}$ \\
\hline Health and wellbeing & $\begin{array}{l}\text { - Has the project enabled greater investment in the } \\
\text { healthcare infrastructure for all? } \\
\text { - How has the project design accommodated concerns } \\
\text { about general wellbeing? }\end{array}$ \\
\hline
\end{tabular}

SOURCE: DOSSANI, BOUEY, AND ZHU (2019) 
The effect and impact of BRI projects are at play at various scales. Some outcomes and impact are limited to the district or city of the infrastructure sites, whereas other impacts loom large at provincial, regional, national and even transnational levels. In developing evaluation metrics, it is important to consider the spillover effect of various costs and benefits and set up measurement of impact at multiple scales.

\subsection{Complexity of Time Horizons}

In evaluating BRI projects, time horizon is a particularly challenging, as many dimensions of project impact are long-term and hard to isolate.

\section{3 Limitations of Current BRI Project Evaluation Frameworks}

We examined the evaluation reports available and summarized the evaluation criteria, data source, and analytic methods used in these studies (see Appendix). Most of the evaluations were released recently in 2018-2019 and provided insights for framework elicitation and evaluation design.

The key characteristics of the existing frameworks is that they tend to single out one impact factor of a project phase at a certain geographic level. In addition, majority of the analysis focuses on the impact of the BRI projects at the country level instead of smaller units of analysis such as states, counties and projects. Project-level analysis is limited due to data transparency issues. Each evaluation focuses on a singular level of analysis (either project-, sectoral or national level) and there is no analysis that addresses BRI projects' impact across different levels and scales. In terms of domain or sector of analysis, existing frameworks mainly focus on trade and investment, transit and travel time, emission data, some social welfare indicators. While there are scant discussions of social and environmental impact with specific indicators, there is hardly any in-depth analysis that describes the wide-ranging socioenvironmental impact of BRI projects. In terms of time horizon, the majority of the proposed framework focuses on effect and impact of BRI project during and after their construction. Given that the bulk of BRI projects are still in the planning and implementation stage, there seems to be scant analysis on evaluation prior to project implementation process.

Various methods are applied in assessing BRI's effect or impact including comparison over time, benchmarking, index composition and simulation. 
In terms of data source, most analyses rely on country-level data, some use provincial- or state-level data. While such analysis could provide an overview of BRI's impact at an aggregate level, they fail to demonstrate BRI project impact at a smaller scale due to lack of project-level data. Granted that there exist project-level commentary and analysis, these do not have a focus on evaluation, unable to generate a set of criteria based on which objective judgements about projects are derived. In addition, critical stakeholders are not involved. Existing assessments were produced by universities, think tanks and multilateral development agencies. While few frameworks mentioned consultation with government departments (Asia Society Policy Institute, 2019), it seems that most evaluation frameworks did not involve stakeholders central to BRI project decision making such as the Chinese government, project host country government, BRI project managers. Neither has affected communities not been involved in conceptualizing or critiquing these frameworks. Rather detached from project planning and implementation, existing evaluation also lacks measurement of project impact based on primary data collection.

What to Include in a B R I Project Evaluation: a Proposed Method

What is an appropriate framework for evaluating mega infrastructure projects such as ones under the Belt and Road Initiative? Given the complexity of stakeholder and domains involved for evaluation, framework elicitation process should address the concerns of multiple stakeholders, domains of impact as well as issues that arise at different project phases. In Table 3 we propose a systematic evaluation framework elicitation method based on the inputs from BRI subject matter experts and verified through stakeholder participation. Stakeholders include decision makers of infrastructure finance lending country government, recipient country government, infrastructure project managers, project staff, local population, local non-governmental organization, multi-lateral development agency representatives, as well as researchers working on BRI and infrastructure finance and program evaluation related research. Sample size for each stakeholder group is of 15 to 20 people. 
TABLE 3 Steps for a proposed evaluation framework elicitation method

\section{Steps Activities}

Step 1 Review of different ways to evaluation B RI projects: review evaluation framework on BRI, large infrastructure projects, megaproject evaluation and sustainable development.

Step 2 Criteria elicitation: elicit dimensions these frameworks capture and generate a master list of dimensions, and generate 1 ) a mutually exclusive and exhaustive list of evaluation dimensions and 2) a list of distinct BRI project categories. Use the evaluation dimensions and project categories to form an evaluation dimension matrix.

Step 3 Criteria application: apply criteria to specific projects to see how they work.

Step 4 Stakeholder opinion elicitation: conduct survey with professional groups of BRI experts, including Chinese experts overseeing BRI projects, local management of BRI projects, international organization staff working on large infrastructure project development. For each project category, three projects representing three types of infrastructure investment will be presented: 1) Chinese funded infrastructure project under the framework of the BRI, 2) projects funded by local government, 3) projects funded by multilateral development agencies, 4) projects funded by a national development agency. In the survey, experts are asked to rank order the importance they attach to each evaluation dimension for each project scenario.

Step 5 Data analysis and framework creation: Then data collected will be analyzed to generate an evaluation framework that captures and convergence and divergence of different stakeholders' objectives. Use the findings from the analysis to inform the design of a new evaluation framework for large infrastructure projects.

Step 6 Verification through case study: conduct three case study by interviewing stakeholders involved in the above mentioned three types of infrastructure projects to verify the feasibility of the frameworks in each case, confirm how evaluation should be scaled for each domain or dimension, and use their feedback to enhance evaluation framework development.

Step 7 Evaluation framework development: adjust the proposed framework based on feedback of stakeholder groups.

Step 8 Specific metrics development: based on the feedback from the projects, generate specific metrics for each impact dimension to be included in the evaluation framework. 
Compared with existing single-scale, single-dimension and single-phased frameworks, our proposed methods will provide a comprehensive and nuanced framework for BRI project evaluation. If used appropriately, it could better reveal benefits or risks of each project and inform more robust decision making for a wide range of stakeholders involved. Lessons learned are not limited to BRI projects and can be transferred to large infrastructure evaluation in other settings.

\section{$5 \quad$ Interim Framework for Project Impact Evaluation}

While the proposed a comprehensive evaluation framework elicitation method provides a way to systematically measure the outcomes and impact of BRI projects, given data availability at a preliminary stage of research, we propose a stakeholder-friendly interim evaluation framework that helps reveal the multifacet developmental impact of BRI projects.

Based on existing challenges of BRI projects, BRI policy objectives and sustainable development framework, we propose an impact evaluation framework to assess sustainable development, presented in Table 4 below. Framework

TABLE 4 Project risk management and sustainability framework

Framework items

Trade and connectivity

Local economic development

Security and geopolitical risks

Project identity

Local enterprise/sme engagement

Local labor inclusion

Technological transfer

Regulations and compliance

Financial sustainability

Environmental sustainability

Social and community

sustainability

Health and wellbeing
Sustainable development goal addressed

Industry, innovation and infrastructure

Economic growth

Peace, justice and strong institutions

Partnerships for the goals

Industry, innovation and infrastructure

Decent work

Innovation

Peace, justice and strong institutions

Economic growth

Climate action, cean water and sanitation, affordable and clean energy

Sustainable cities and communities

Gender equality

Good health and hell-being

SOURCE: DOSSANI, BOUEY, AND ZHU (2019) 
items are elicited based on existing BRI evaluation framework and the areas of challenges common to BRI projects across the world, and the Sustainable Development Goals provide a convenient tool for categorizing project impact. Compared with existing evaluation framework, it includes multiple domains of project impact, targets project impact at multiple scales, and seeks to combine data from multiple project phases.

Following the steps proposed in Table 3 for evaluation framework elicitation, and using the proposed interim evaluation framework in Table 4, we conducted a preliminary assessment of the Mombasa-Nairobi Standard Gauge Railway (SGR) in Kenya as a preliminary proof of concept that demonstrates the utility of a holistic megaproject evaluation framework. Compared with existing studies of the SGR that focus on singular aspects such as political dynamics (Wang 2019; Wissenbach and Wang, 2017), national development (Irandu, 2017), technological transfer (Chenge et al., 2019), and environmental footprints (Jiang, 2020; Ambani, 2017), our approach comprehensively assesses of early-stage outcomes of the SGR, and provides a structured approach to analyzing longer term impact of the project.

\subsection{Connectivity and Trade}

At a cost of US $\$ 3.8$ billion (Railway Technology, 2016), the SGR is Kenya's most expensive infrastructure project since independence, the first railway built in Kenya in the past century, and a flagship project in China-Africa cooperation. Construction started in 2014 and was completed in 2017, when the railway was inaugurated. It runs parallel to the now-closed narrow-gauge Uganda Railway that was completed in 1901 under British colonial rule and has shortened the Nairobi-Mombasa travel time from over 10 hours to 4.5 hours. The railway carries both passengers (at $120 \mathrm{~km} / \mathrm{h}$ ) and freight (at $80 \mathrm{~km} / \mathrm{h}$ ). The development of the SGR offsets burden on roads saves potential cost incurred by road maintenance and enhances freight security in transit. It also helps promote a better mix of rail and road transportation to formulate a well-balanced multi-modal transportation system.

1 This case study builds on my earlier co-authored work Dossani, Bouey, and Zhu (2019). 
TABLE 5 Facts on the Standard Gauge Railway project, Kenya

\begin{tabular}{|c|c|}
\hline Contract Amount & US $\$ 3.804$ billion \\
\hline Funding agency & $\begin{array}{l}\text { The government of the Republic of Kenya }(15 \%) \text { and } \\
\text { the Export-Import Bank of China }(85 \%)\end{array}$ \\
\hline Client & Kenya Railway Corporation (KRC) \\
\hline EPC contractor & China Road and Bridges Corporation (CRBC) \\
\hline Date of Commencement & 12 December 2014 \\
\hline Duration of Construction & 60 months \\
\hline Operator & China Road and Bridge Corporation (CRBC) \\
\hline Characteristics & $\begin{array}{l}\text { Single-track non-electric SGR from Mombasa to Nairobi } \\
\text { (phase } 1 \text { ) and Naivasha (phase } 2 \mathrm{~A} \text { ); freight trains of up } \\
\text { to } 8 \text { o kilometers per hour and passenger trains at up to } \\
120 \mathrm{~km} / \mathrm{hr} \text {. }\end{array}$ \\
\hline
\end{tabular}

SOURCE: CHINA ROAD AND BRIDGE CORPORATION SOCIAL RESPONSIBILITY REPORT ON MOMBASA NAIROBI SGR PROJECT

Before the construction of the SGR, key regional corridors in Kenya were performing poorly, partly due to poor connectivity and weak transportation capacity (Adero and Aligula, 2012). The aged and dilapidated Meter Gauge Railway could handle $5.5 \%$ of the total traffic in Kenya's North Corridor and 6.2 of the total traffic of the Central Corridor, and road transportation used to handle the bulk of traffic along both Corridors (Irandu, 2017). The SGR increases cargo throughput by rail and lower transport costs and time by as much as $6 \circ \%$ (Wissenbach and Wang, 2017). Once the railway is connected with other parts of Kenya and its neighboring country to form a regional railway network, the SGR will significantly promote efficient and effective movement of goods and services, increases productivity of regional transportation system, and lowers cost of doing business in the region. Better connectivity powered by SGR development can break down the transportation bottleneck of the East African Community and serves as asset for the region's future growth.

\subsection{Local Economic Development}

A flagship project under Kenya's Vision 2030, which aims at transforming Kenya into a middle-income industrialized economy by 2030 (CRBC, 2016). During construction, the railway reportedly increased Kenyan annual GDP by $1.5 \%$, and reduced logistics cost by $40 \%$. When completed, the railway will span the 


\section{Kenya's Railway to Nowhere}

Construction of a Chinese-built line across East Africa has halted

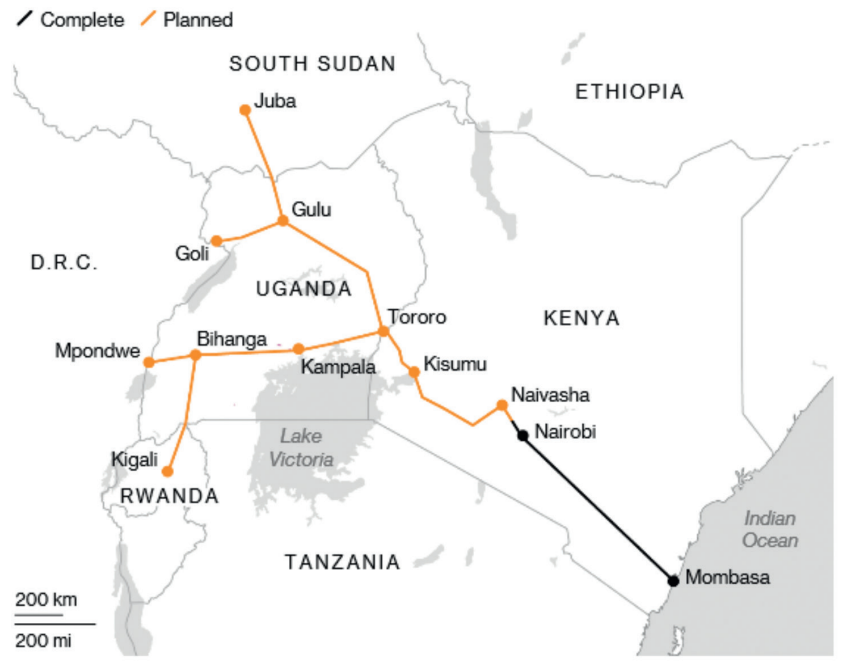

Note: Map shows only selected stops

Source: Kenyan and Ugandan government documents

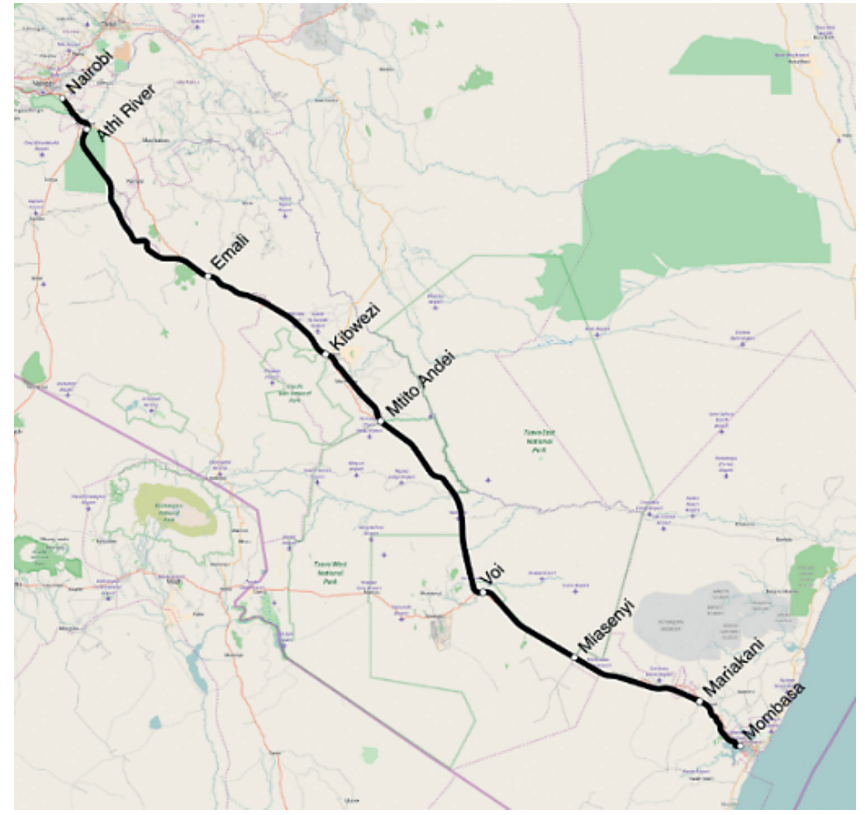

FIGURE 1 Illustration of the railway network plan and the

Nairobi-Mombasa Standard Gauge Railway SOURCE: KENYAN AND UGANDAN GOVERNMENT DOCUMENTS AND OPENSTREETMAP (http://www.openstreetmap.org) 
country and open corridors to Uganda, South Sudan and Rwanda. North of Kenya is the Lamu-Port-South Sudan-Ethiopia Transportation Corridor, a network of ports, highways, railway, oil refineries and a coal plant. The SGR will thus accelerate economic integration and regional economic cooperation. The project also strengthens Kenya's infrastructure and connectivity compared with its regional competitors such as Tanzania, and help the country develop long-term comparative advantage.

\subsection{Security and Geopolitics}

To date, there is no reported military involvement of China in the SGR. What should be noted is the changing economic dynamics that gives rise to geopolitical risks. Under the SGR development agreement, part of the goods that used to go through customs clearance in Mombasa are now transferred to Nairobi for the process, which increases the revenue for Nairobi and in turn weakens the economic capacity of Mombasa, where the opposition party dominates. Thus, change of economic dynamics shifts geopolitical dynamics within the country, which has become a key reason for the political resistance against the project.

\subsection{Project Identity}

China-Exim Bank provided $85 \%$ of the financing for the SGR (with a combination of commercial loan and concessional loan), and the Kenyan Government contributed $15 \%$. The Kenyan Government is highly supportive of the development of the SGR. It regards the railway as a key step for Kenya towards becoming an industrialized middle-income country, as detailed in Kenya's Vision 2030. Note that the government is operating the projects after completion. In summary, there is high sense of partnership and commitment of the state. Based on over 10o interviews, Wang and Wissenbach (2019) observed that both Kenyan and Chinese sides repeatedly emphasized that the SGR is a 'Kenyan railway', with technical and financial support from China. China Road and Bridges Corporation leaves ethnic conflicts, land distributes, or politics of business in Kenya to the relevant bodies of the Kenyan government and limit its role to technical aspects of railway construction. The Government of Kenya is thus able to exercise its agency in the process and drive results desirable for the Kenyan government and enterprises.

\subsection{Local Enterprise}

As a result of the Kenyan government's significant agency ability to negotiate with the China Road and Bridges Corporation, President Kenyatta pushed for 
and publicly announced that the SG R would locally source $40 \%$ materials, services, and employment, which is 10\% higher than Exım Bank's requirement of $70 \%$ of Chinese products in overseas infrastructure projects (Wang and Wissenbach, 2019). This provides local businesses with significant opportunities in providing raw materials and services. The SGR, by increasing passenger transit speed and volume, also provide local businesses with more tourists to cater. For example, two years into the operation of the Mombasa-Nairobi SGR, hotel occupancy rate in Mombasa turned from $50 \%$ to $90 \%$. Between January 2017 and May 2018, SGR has generated 26,706 jobs and involved 378 local enterprises in sub-contract work (CRBC, 2018).

\subsection{Local Labor Inclusion}

According to Social Corporate Responsibility Report of CRBC (2018), the SGR provided 46,ooo jobs and trained 5000 local staff during construction. Local staff constitute $76 \%$ of the workforce (CRBC, 2017). The objective is to systematically reduce the percentage of Chinese staff and achieve $90 \%$ local staff rate by 2027 .

\subsection{Technological Transfer}

CITIC responded to Kenya's needs for technological transfer by providing different types of training including apprenticeships, off-the-job training and onthe-job training to promote management skills and technological standards. As of June 2019, most basic service and integrated management positions have been localized. According to official reports, four Kenyan staff support the core function of command and dispatch; 11 Kenyans have obtained licenses to independently operate the trains; in 25 out of 33 stations, the entire management has been transferred to Kenyan staff, and the customer service, train service and passenger transfer management have been transferred with a staff localization rate of over $90 \%$ in 9 of the stations (FOCAC, 2019). The operating company of the SGR has hired and employed over 1,ooo local staff and developed specialized on-the-job training in collaboration between Kenyan and Chinese universities and occupational training programs. By 2017, it has trained 858 local staff in five categories of jobs including freight service, passenger service, mechanical engineering, electronic engineering and railway transportation control (Embassy of China in Kenya, 2019).

Meanwhile, there are still criticisms on the short-term nature of training and lack of comprehensive and systematic workforce training on railway 
technology development. To address the long-term technological transfer needs of the railway industry in Kenya, CRBC started collaboration with Southwest University in China and Kenya Railway Training Institute (RTI) to operate training program. Together with Kenya Railway Corporation, it has established the East Africa Railway Technology Training Center (CRBC, 2017). In the past three years, CRBC has sent a total of 100 Kenyan high-school graduates to pursue Bachelor's degree in railway construction and operation in Beijing Jiaotong University for comprehensive knowledge and skills development (CRBC, 2018).

\subsection{Regulations, Compliance and Corruption}

Governance remains a prominent problem in the region and corruption remain a central concern in media coverage of the SGR, which fuels a growing distrust of the government. Criticism of corruption centers around cost of the railway (Kacungira, 2017), pricing mechanism and lack of transparency with SGR construction and operation agreements. Kenyan authorities arrested the head of the agency that managed public land and the head of the state railway on suspicion of corruption over land allocation for the SGR (Reuters, 8.1.2018) and arrested seven officials with the CRBC for bribing investigators looking into corruption tied to the SGR (Daily Nations, 2018).

\subsection{Financial Sustainability}

This is an area attracting most of the criticism and query about the project. The SGR was financed by Chinese Exim Bank loans of US $\$ 3.2$ bn (ввC, 2017). The repayment period for the loan is 20 years, with an annual interest of $2 \%$ (FOCAC, 2017). With the unprecedented investment came the concern that Kenya risked losing the port of Mombasa to China Exim Bank should the government default (Daily Nations, 2019, November 6 and 2019, May 29). The President of Kenya denied the accusation and acknowledged China as a strong development partner similar to the World Bank, Japan, France and Germany (FOCAC, 2019). Kenya's net borrowing has also shrunk to $5.2 \%$ of GDP from $6.7 \%$ according to IMF data. As of March 2018, China accounts for $72 \%$ of bilateral debt (Business Daily, 2018), with a 15-percentage increase from the 2016 data. Overall, China accounts for over $21 \%$ of Kenya's external debt (Quarts Africa, 2018). Debt to GDP significantly increased, from $38.2 \%$ in 2012 to $55.5 \%$ by April 2019 (The Star, 2019), but is still under the generally accepted sustainable threshold of $60 \%$ for a developing economy. 


\subsection{Environmental Sustainability}

The railway goes from southeast to northwest, moving along the largest national wildlife park in the country, with an overlap of $120 \mathrm{~km}$. Environmental and ecological concerns were expressed during the construction of the railway. At the design phase, the railway established green standards in route selection and construction. It introduced environmental conservation good practices from A50 Highway in the Netherlands, B38 Highway in Germany, and Qinghai-Tibet Railway in China. Over 20 rounds of consultations were conducted, from the Kenyan government, wildlife protection organizations and local residents. By building a railroad parallel to the existing railway and highway and establishing wildlife passages in the middle of the railroad, the railway was able to reduce the biodiversity and ecological impact of the railway. Research was conducted in collaboration with the Bureau for Wildlife Protection in Kenya, on wild animals' living habits and migration patterns, and established bridges as passage for animals, and built drinking stations for smaller animals. 61 bridges, 14 animal passages, 600 anti-flood and fly-over culverts were built during construction. Based on observation, the animal passages are being used by wild animals. CRBC has contracted the Africa Waste and Environment Management Center to conduct Environmental and Social Impact Assessment Study for the proposed Mombasa-Nairobi RGR (2012). Ministry of Transport, Infrastructure, Housing and Urban Development also conducted environmental and social assessments (2017).

Despite these efforts, there were environmentalist protests, according to media reports. There are reported damage (Ndiho Media, 2018) of fence set up by wildlife. Humans are drawn to the overpasses because they create park access for livestock and scavenging. Because of these human settlements, wildlife holds back, rendering the wildlife underpass useless. There was also reportage from the Chinese media on the death of elephants caused by railway operations.

\subsection{Social and Community}

The SGR is expected to promote regional integration. The East African Railway Master Plan provides for the Mombasa-Nairobi SGR to link with other SGRS being built in the East Africa Community. The ultimate vision is to build a railroad of 2,700 km connecting Kenya, Tanzania, Uganda, Rwanda Burundi and South Sudan. The development of the railway also triggered travelling pattern and lifestyle change within Kenya, as exemplified the change of hotel occupancy rate from $50 \%$ to $90 \%$ in Mombasa due to increase of domestic travel (FOCAC, 2019). There is potential for the railway to transform the migration 
pattern, shatter the foundations for tribe-based society and fundamentally transform the social, economic and political structure of the country, although longitudinal tracking and data gathering is missing at this stage.

CRBC has invested US\$27.6 million in corporate social responsibility related activities. Over 260 community engagement activities have been conducted, including the building of 3 schools, digging wells for local community water access, donation to children, road building and transport of disaster relief grain (CRBC, 2015, 2017, 2018).

\subsection{Health and Wellbeing}

Reduced use of road transportation reduces road accidents and helps prevent road-related injuries and mortality. Long-distance truck drivers are at a higher risk of exposure to HIV/AIDS and are more likely to spread it along truck routes. With SGR's development, the number of trucks driver on the road will likely decline and could thus reduce the HIV/AIDS transmission rate through this transmission route. Increasing use of railway instead of highway could also reduce the number of road accidents and may increase the healthcare access for people in remote areas by providing an additional transportation option. Yet the spillover effect could work in an opposite direction due change in mobility. Kenyan government agency attributed high HIV/AIDS rate to ongoing road and railroad construction (Business and Human Rights Center, 2016). News report points out that HIV infection doubling in counties along the SGR (The Star, 2019), which could have been attributed to increasing mobility and lifestyle change. The long-term impact of the SGR on health and wellbeing remains to be closely tracked.

In the recent pandemic in Kenya in 2020, SGR was also suggested to have contributed to mitigating the spread of Covid-19 through effective containment measures (Xinhua, 2020, July 7), as well as transportation of medical supplies for epidemic control (Xinhua, 2020, November 5 ).

\section{$7 \quad$ Conclusion}

We summarize the results of our assessments using the framework below.

We use color green to indicate areas where positive outcomes and satisfactory performance have been observed. From the perspectives of trade and connectivity, impact on local economy, project ownership and identity, benefits to local enterprises and business development, local labor inclusion, technological and skills transfer, engagements with local community, and effect on 

requirements)

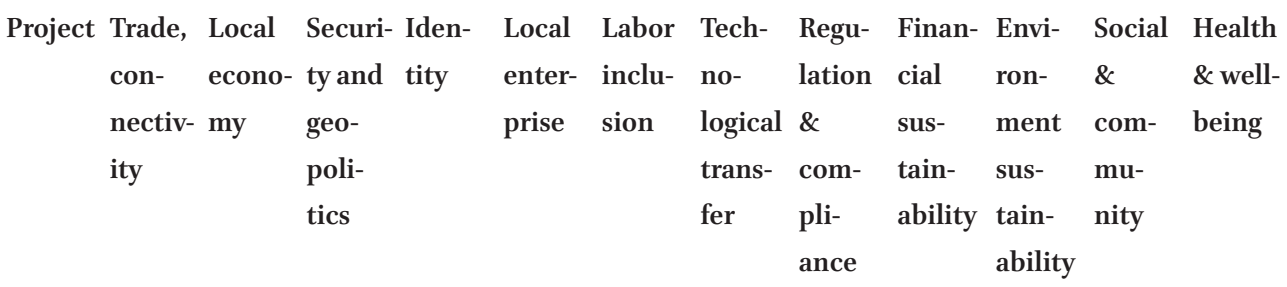

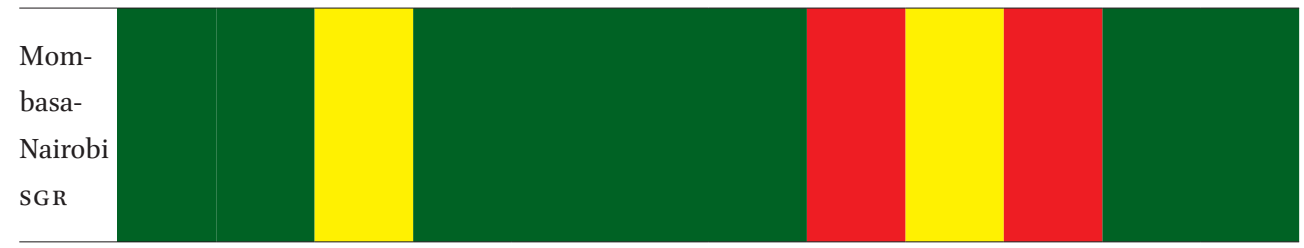

SOURCE: DOSSANI (2018), DOSSANI, BOUEY, AND ZHU (2019)

health and wellbeing, the SGR has produced generally positive outcomes and benefited local community and the country at large in the first two years of its operation. We use color yellow to indicate areas where we think that the SGR pose minor threats that may affect future success of the project and may generate negative outcomes and impacts if not managed properly. Based on our analysis, the SGR is likely to face increasing tensions in security- and geopolitics-related issues due to domestic politics and international competition, and may also encounter financial sustainability issues if debt level becomes increasingly unmanageable. We use color red to indicate areas where negative procedures and outcomes have been observed, and where negative outcomes have generated major controversies in Kenya. Corruption and environmental sustainability are two of the biggest concern at this stage of development, and have triggered fervent debates and discussions that may fuel major disputes in future. Policymakers need to carefully consider the areas of assessment discussed above, and pay special attentions to areas with negative outcomes and potentially dire consequence, and design policy measures that strengthen these areas of development to lower the risks and minimize the negative impacts.

The case study of the SGR, a flagship BRI project in Africa, demonstrates the importance of local identity and ownership, local business participation, local labor inclusion, technological transfer and localization, regulation compliance, as well as the significance of environmental, social and health related measures and considerations in BRI project planning, design, construction 
and operations. Other areas including local engagement, socio-environmental impacts and community health and wellbeing implications have not received sufficient consideration in our case study, nor have they been sufficiently incorporated in analysis of other BRI projects. A holistic project assessment framework can help promote a balanced approach to project implementation, and generate sustainable development for different stakeholders involved in the BRI.

Our proposed framework is rather preliminary at this stage, and more indepth research is required to identify best practices in program evaluation framework design and implementation. The case study demonstrates the use of an evaluative perspective in understanding project outcomes. Longitudinal tracking of the SGR project is needed to understand new developments and challenges in project operation, so as to incorporate emerging project needs and concerns into the design of BRI project evaluation. Future research should also seek to identify ways to bridge BRI project evaluation and other international large and mega infrastructure project evaluation schemes, which will allow comparison of project processes, outcomes and impacts, and inform more objective assessment of BRI projects and megaprojects at large.

\section{Appendix: Existing Evaluation Framework of BRI or BRI Projects}

\begin{tabular}{|c|c|c|c|c|c|c|c|}
\hline Title & $\begin{array}{l}\text { Time } \\
\text { released }\end{array}$ & $\begin{array}{l}\text { What is the } \\
\text { evaluation about? }\end{array}$ & $\begin{array}{l}\text { Who are the } \\
\text { evaluators? }\end{array}$ & $\begin{array}{l}\text { What's the } \\
\text { level of } \\
\text { analysis? }\end{array}$ & $\begin{array}{l}\text { What } \\
\text { evalua- } \\
\text { tion tools } \\
\text { are pro- } \\
\text { posed? }\end{array}$ & $\begin{array}{l}\text { What is } \\
\text { the source } \\
\text { of data? }\end{array}$ & $\begin{array}{l}\text { What } \\
\text { analytical } \\
\text { methods } \\
\text { were } \\
\text { applied? }\end{array}$ \\
\hline $\begin{array}{l}\text { Grading } \\
\text { China's } \\
\text { Belt and } \\
\text { Road }\end{array}$ & 2019 & 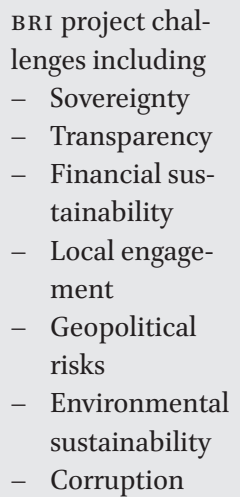 & $\begin{array}{l}\text { Center for } \\
\text { New American } \\
\text { Security (think } \\
\text { tank) }\end{array}$ & Project & Checklist & $\begin{array}{l}\text { BRI project } \\
\text { informa- } \\
\text { tion from } \\
\text { reports } \\
\text { and media } \\
\text { accounts }\end{array}$ & $\begin{array}{l}\text { Case } \\
\text { study }\end{array}$ \\
\hline
\end{tabular}


(cont.)

\begin{tabular}{|c|c|c|c|c|c|c|c|}
\hline Title & $\begin{array}{l}\text { Time } \\
\text { released }\end{array}$ & $\begin{array}{l}\text { What is the } \\
\text { evaluation about? }\end{array}$ & $\begin{array}{l}\text { Who are the } \\
\text { evaluators? }\end{array}$ & $\begin{array}{l}\text { What's the } \\
\text { level of } \\
\text { analysis? }\end{array}$ & $\begin{array}{l}\text { What } \\
\text { evalua- } \\
\text { tion tools } \\
\text { are pro- } \\
\text { posed? }\end{array}$ & $\begin{array}{l}\text { What is } \\
\text { the source } \\
\text { of data? }\end{array}$ & $\begin{array}{l}\text { What } \\
\text { analytical } \\
\text { methods } \\
\text { were } \\
\text { applied? }\end{array}$ \\
\hline $\begin{array}{l}\text { Navigating } \\
\text { the Belt } \\
\text { and Road } \\
\text { Initiative }\end{array}$ & 2019 & $\begin{aligned} &- \text { Respecting } \\
& \text { sovereignty } \\
&- \text { Project prepara- } \\
& \text { tion assessment } \\
& \text { and analysis } \\
&- \text { Environmental } \\
& \text { and social im- } \\
& \text { pact assessment } \\
&- \text { Project financing } \\
& \text { and debt } \\
&- \text { Local stakehold- } \\
& \text { er engagement } \\
&- \text { Incorporating } \\
& \text { local labor, } \\
& \text { businesses, and } \\
& \text { training } \\
&- \text { Competition and } \\
& \text { transparency } \\
&- \text { Corruption } \\
&- \text { Project oversight } \\
& \text { and coordination }\end{aligned}$ & $\begin{array}{l}\text { Asia Society } \\
\text { Policy Institute } \\
\text { (think tank) }\end{array}$ & Project & Checklist & $\begin{array}{l}\text { BRI project } \\
\text { informa- } \\
\text { tion from } \\
\text { reports } \\
\text { and media } \\
\text { accounts }\end{array}$ & $\begin{array}{l}\text { Case } \\
\text { study }\end{array}$ \\
\hline
\end{tabular}


(cont.)

\begin{tabular}{|c|c|c|c|c|c|c|c|}
\hline Title & $\begin{array}{l}\text { Time } \\
\text { released }\end{array}$ & $\begin{array}{l}\text { What is the } \\
\text { evaluation about? }\end{array}$ & $\begin{array}{l}\text { Who are the } \\
\text { evaluators? }\end{array}$ & $\begin{array}{l}\text { What's the } \\
\text { level of } \\
\text { analysis? }\end{array}$ & $\begin{array}{l}\text { What } \\
\text { evalua- } \\
\text { tion tools } \\
\text { are pro- } \\
\text { posed? }\end{array}$ & $\begin{array}{l}\text { What is } \\
\text { the source } \\
\text { of data? }\end{array}$ & $\begin{array}{l}\text { What } \\
\text { analytical } \\
\text { methods } \\
\text { were } \\
\text { applied? }\end{array}$ \\
\hline $\begin{array}{l}\text { A Frame- } \\
\text { work to } \\
\text { assess } \\
\text { debt } \\
\text { sustain- } \\
\text { ability and } \\
\text { fiscal risks } \\
\text { under the } \\
\text { Belt and } \\
\text { Road Ini- } \\
\text { tiative }\end{array}$ & 2019 & 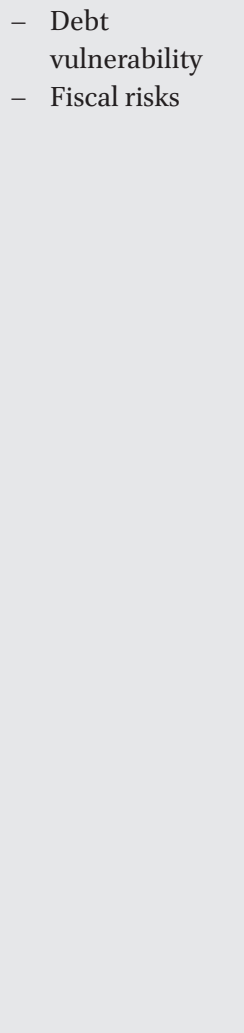 & $\begin{array}{l}\text { World Bank } \\
\text { (international } \\
\text { organization) }\end{array}$ & Country & $\begin{array}{l}\text { Eco- } \\
\text { nomic } \\
\text { modeling } \\
\text { using } \\
\text { existing } \\
\text { data } \\
\text { Checklist } \\
\text { of } \\
\text { sources } \\
\text { of debt } \\
\text { vulner- } \\
\text { abilities } \\
\text { and fiscal } \\
\text { risks }\end{array}$ & $\begin{array}{l}\text { Lend- } \\
\text { ing from } \\
\text { China to } \\
5 \text { o of the } \\
65 \text { BRI } \\
\text { countries } \\
\text { from } \\
\text { AidData } \\
\text { and sAIs- } \\
\text { CARI, wB's } \\
\text { Debtor } \\
\text { Reporting } \\
\text { System for } \\
\text { validity } \\
\text { Survey of } \\
\text { BRI- } \\
\text { related } \\
\text { investment } \\
\text { commis- } \\
\text { sioned by } \\
\text { the World } \\
\text { Bank and } \\
\text { compiled } \\
\text { by winD, } \\
\text { a Chinese } \\
\text { consultan- } \\
\text { cy firm }\end{array}$ & $\begin{array}{l}\text { Foresight } \\
\text { analysis } \\
\text { debt and } \\
\text { growth } \\
\text { elasticities } \\
\text { to invest- } \\
\text { ment, to } \\
\text { project } \\
\text { the evolu- } \\
\text { tion of } \\
\text { debt- to- } \\
\text { GDP ratio } \\
\text { in BRI- } \\
\text { recipient } \\
\text { countries }\end{array}$ \\
\hline
\end{tabular}

a http://documents.worldbank.org/curated/en/72367156o782662349/pdf/A-Framework-toAssess-Debt-Sustainability-and-Fiscal-Risks-under-the-Belt-and-Road-Initiative.pdf. 
(cont.)

\begin{tabular}{|c|c|c|c|c|c|c|c|}
\hline Title & $\begin{array}{l}\text { Time } \\
\text { released }\end{array}$ & $\begin{array}{l}\text { What is the } \\
\text { evaluation about? }\end{array}$ & $\begin{array}{l}\text { Who are the } \\
\text { evaluators? }\end{array}$ & $\begin{array}{l}\text { What's the } \\
\text { level of } \\
\text { analysis? }\end{array}$ & $\begin{array}{l}\text { What } \\
\text { evalua- } \\
\text { tion tools } \\
\text { are pro- } \\
\text { posed? }\end{array}$ & $\begin{array}{l}\text { What is } \\
\text { the source } \\
\text { of data? }\end{array}$ & $\begin{array}{l}\text { What } \\
\text { analytical } \\
\text { methods } \\
\text { were } \\
\text { applied? }\end{array}$ \\
\hline $\begin{array}{l}\text { Common } \\
\text { transport } \\
\text { infrastruc- } \\
\text { ture: a } \\
\text { quan- } \\
\text { titative } \\
\text { model and } \\
\text { estimates } \\
\text { from the } \\
\text { Belt and } \\
\text { Road } \\
\text { Initiative }\end{array}$ & 2019 & $\begin{array}{l}\text { Effect on trade, } \\
\text { welfare, and gross } \\
\text { domestic product } \\
\text { of common } \\
\text { transport } \\
\text { infrastructure }\end{array}$ & $\begin{array}{l}\text { World Bank } \\
\text { (international } \\
\text { organization) }\end{array}$ & $\begin{array}{l}\text { Country } \\
\text { Sector }\end{array}$ & $\begin{array}{l}\text { Quantify } \\
\text { tool for } \\
\text { BRI's } \\
\text { effect on } \\
\text { trade, } \\
\text { welfare, } \\
\text { and GDP } \\
\text { for coun- } \\
\text { tries of } \\
\text { different } \\
\text { income } \\
\text { levels and } \\
\text { regions } \\
\text { One } \\
\text { equa- } \\
\text { tion per } \\
\text { country }\end{array}$ & $\begin{array}{l}\text { Data from } \\
\text { GTAP } 10 \\
\text { of } 107 \\
\text { countries, } \\
\text { regions } \\
\text { and } 31 \\
\text { sectors }\end{array}$ & $\begin{array}{l}\text { Structural } \\
\text { general } \\
\text { equilib- } \\
\text { rium } \\
\text { model } \\
\text { Geogra- } \\
\text { phy Infor- } \\
\text { mation } \\
\text { System }\end{array}$ \\
\hline
\end{tabular}

\begin{tabular}{|c|c|c|c|c|c|c|c|}
\hline $\begin{array}{l}\text { The Belt } \\
\text { and Road } \\
\text { initiative: } \\
\text { Reshaping } \\
\text { Economic } \\
\text { Geogra- } \\
\text { phy in } \\
\text { Central } \\
\text { Asia }\end{array}$ & 2019 & $\begin{array}{l}\text { Effect of BRI on } \\
\text { employment in } \\
\text { manufacturing, } \\
\text { export trade cost, } \\
\text { import trade cost } \\
\text { in Central Asian } \\
\text { economies }\end{array}$ & $\begin{array}{l}\text { World Bank } \\
\text { (international } \\
\text { organization) }\end{array}$ & $\begin{array}{l}\text { Country } \\
\text { Region }\end{array}$ & $\begin{array}{l}\text { Eco- } \\
\text { nomic } \\
\text { model to } \\
\text { quantify } \\
\text { BRI's } \\
\text { effect on } \\
\text { employ- } \\
\text { ment, } \\
\text { trade } \\
\text { cost }\end{array}$ & $\begin{array}{l}\text { Employ- } \\
\text { ment, } \\
\text { popula- } \\
\text { tion, land } \\
\text { area, } \\
\text { national } \\
\text { accounts } \\
\text { data on } \\
\text { Gross } \\
\text { Value } \\
\text { Added } \\
\text { by sector, } \\
\text { trade data, } \\
\text { travel time } \\
\text { data from } \\
\text { national } \\
\text { statistical } \\
\text { bureau, } \\
\text { UN, wB } \\
\text { data } \\
\text { base and } \\
\text { existing } \\
\text { simulation } \\
\text { results }\end{array}$ & $\begin{array}{l}\text { Com- } \\
\text { putable } \\
\text { spatial } \\
\text { equi- } \\
\text { librium } \\
\text { model }\end{array}$ \\
\hline
\end{tabular}


(cont.)

\begin{tabular}{|c|c|c|c|c|c|c|c|}
\hline Title & $\begin{array}{l}\text { Time } \\
\text { released }\end{array}$ & $\begin{array}{l}\text { What is the } \\
\text { evaluation about? }\end{array}$ & $\begin{array}{l}\text { Who are the } \\
\text { evaluators? }\end{array}$ & $\begin{array}{l}\text { What's the } \\
\text { level of } \\
\text { analysis? }\end{array}$ & $\begin{array}{l}\text { What } \\
\text { evalua- } \\
\text { tion tools } \\
\text { are pro- } \\
\text { posed? }\end{array}$ & $\begin{array}{l}\text { What is } \\
\text { the source } \\
\text { of data? }\end{array}$ & $\begin{array}{l}\text { What } \\
\text { analytical } \\
\text { methods } \\
\text { were } \\
\text { applied? }\end{array}$ \\
\hline $\begin{array}{l}\text { The Belt } \\
\text { and Road } \\
\text { Initiative: } \\
\text { Economic, } \\
\text { Poverty } \\
\text { and Envi- } \\
\text { ronmental } \\
\text { impacts }\end{array}$ & 2019 & $\begin{array}{l}\text { - } \text { Trade cost } \\
\text { reduction } \\
\text { - } \text { Macro results: } \\
\text { real income, } \\
\text { distribution of } \\
\text { gains between } \\
\text { China and BRI } \\
\text { host countries, } \\
\text { BRI and non-BRI } \\
\text { countries, global } \\
\text { export and } \\
\text { import growth, } \\
\text { trade volume, } \\
\text { value of the time } \\
\text { of trade, value } \\
\text { added, factor }\end{array}$ & $\begin{array}{l}\text { World Bank } \\
\text { (international } \\
\text { organization) }\end{array}$ & Country & $\begin{array}{l}\text { List of } \\
\text { indica- } \\
\text { tors to } \\
\text { measure } \\
\text { economic } \\
\text { effects } \\
\text { and tool } \\
\text { to project } \\
\text { social } \\
\text { and } \\
\text { environ- } \\
\text { mental } \\
\text { benefits } \\
\text { Projec- } \\
\text { tion by } \\
2030\end{array}$ & GTAP & $\begin{array}{l}\text { Simula- } \\
\text { tion ex- } \\
\text { periment } \\
\text { using } \\
\text { Envisage } \\
\text { Model - a } \\
\text { global, } \\
\text { recursive } \\
\text { dynamic } \\
\text { comput- } \\
\text { able } \\
\text { general } \\
\text { equilibri- } \\
\text { um model }\end{array}$ \\
\hline
\end{tabular}

- Social benefits: factor rewards, labor displacement and poverty implications, emissions implications ( $\mathrm{CO}_{2}, \mathrm{CH}_{4}, \mathrm{~N}_{2} \mathrm{O}$, FGAS, BC, CO, $\mathrm{NH}_{3}, \mathrm{NMVB}$, NMVF, Nox, OC, PM 10, PM 2_5, $\mathrm{SO} 2$ ), welfare gains 
(cont.)

\begin{tabular}{|c|c|c|c|c|c|c|c|}
\hline Title & $\begin{array}{l}\text { Time } \\
\text { released }\end{array}$ & $\begin{array}{l}\text { What is the } \\
\text { evaluation about? }\end{array}$ & $\begin{array}{l}\text { Who are the } \\
\text { evaluators? }\end{array}$ & $\begin{array}{l}\text { What's the } \\
\text { level of } \\
\text { analysis? }\end{array}$ & $\begin{array}{l}\text { What } \\
\text { evalua- } \\
\text { tion tools } \\
\text { are pro- } \\
\text { posed? }\end{array}$ & $\begin{array}{l}\text { What is } \\
\text { the source } \\
\text { of data? }\end{array}$ & $\begin{array}{l}\text { What } \\
\text { analytical } \\
\text { methods } \\
\text { were } \\
\text { applied? }\end{array}$ \\
\hline $\begin{array}{l}\text { Who } \\
\text { wins, who } \\
\text { loses? Un- } \\
\text { derstand- } \\
\text { ing the } \\
\text { spatially } \\
\text { differ- } \\
\text { entiated } \\
\text { effects of } \\
\text { the Belt } \\
\text { and Road } \\
\text { Initiative }\end{array}$ & 2019 & $\begin{array}{l}\text { - How regions } \\
\text { within countries } \\
\text { adjust to trade } \\
\text { and transport } \\
\text { shocks in Central } \\
\text { Asia } \\
\text { - Aggregate trends: } \\
\text { all roads, exter- } \\
\text { nal and internal } \\
\text { integration, } \\
\text { export potential } \\
\text { A model of struc- } \\
\text { tural change } \\
\text { and integra- } \\
\text { tion: household } \\
\text { heterogeneous } \\
\text { preferences } \\
\text { for locations, } \\
\text { consumption, } \\
\text { mobility across } \\
\text { locations, } \\
\text { production } \\
\text { technology } \\
\text { Economic } \\
\text { and welfare } \\
\text { impacts of large } \\
\text { transport and } \\
\text { border invest- } \\
\text { ment in China } \\
\text { and Central } \\
\text { Asia: transport } \\
\text { connections, } \\
\text { border times, } \\
\text { migration costs, } \\
\text { wage inequality, } \\
\text { national welfare }\end{array}$ & $\begin{array}{l}\text { World Bank } \\
\text { (international } \\
\text { organization) } \\
\text {. }\end{array}$ & $\begin{array}{l}\text { Regions } \\
\text { within } \\
\text { country }\end{array}$ & $\begin{array}{l}\text { A model } \\
\text { of } \\
\text { structural } \\
\text { change } \\
\text { and inte- } \\
\text { gration }\end{array}$ & $\begin{array}{l}\text { District } \\
\text { admin- } \\
\text { istration } \\
\text { data, land } \\
\text { data from } \\
\text { European } \\
\text { Satellite } \\
\text { Agency, } \\
\text { employ- } \\
\text { ment in } \\
\text { tradables } \\
\text { sector, } \\
\text { transport } \\
\text { costs, } \\
\text { migration } \\
\text { costs }\end{array}$ & $\begin{array}{l}\text { Quan- } \\
\text { titative } \\
\text { economic } \\
\text { geography } \\
\text { model } \\
\text { New } \\
\text { Economic } \\
\text { Geogra- } \\
\text { phy }\end{array}$ \\
\hline
\end{tabular}


(cont.)

\begin{tabular}{|c|c|c|c|c|c|c|c|}
\hline Title & $\begin{array}{l}\text { Time } \\
\text { released }\end{array}$ & $\begin{array}{l}\text { What is the } \\
\text { evaluation about? }\end{array}$ & $\begin{array}{l}\text { Who are the } \\
\text { evaluators? }\end{array}$ & $\begin{array}{l}\text { What's the } \\
\text { level of } \\
\text { analysis? }\end{array}$ & $\begin{array}{l}\text { What } \\
\text { evalua- } \\
\text { tion tools } \\
\text { are pro- } \\
\text { posed? }\end{array}$ & $\begin{array}{l}\text { What is } \\
\text { the source } \\
\text { of data? }\end{array}$ & $\begin{array}{l}\text { What } \\
\text { analytical } \\
\text { methods } \\
\text { were } \\
\text { applied? }\end{array}$ \\
\hline $\begin{array}{l}\text { Trade } \\
\text { effects of } \\
\text { the New } \\
\text { Silk Road: } \\
\text { a gravity } \\
\text { analysis }\end{array}$ & 2019 & $\begin{array}{r}\text { Estimated } \\
\text { trade time }\end{array}$ & $\begin{array}{l}\text { World Bank } \\
\text { (international } \\
\text { organization) }\end{array}$ & Country & $\begin{array}{l}\text { Simula- } \\
\text { tion } \\
\text { results }\end{array}$ & $\begin{array}{l}\text { Geo- } \\
\text { referenced } \\
\text { data }\end{array}$ & $\begin{array}{l}\text { Geograph- } \\
\text { ical infor- } \\
\text { mation } \\
\text { system } \\
\text { analysis, } \\
\text { network } \\
\text { analysis }\end{array}$ \\
\hline
\end{tabular}

\begin{tabular}{|c|c|c|c|c|c|c|c|c|}
\hline $\begin{array}{l}\text { Grading } \\
\text { China's } \\
\text { Belt and } \\
\text { Road }\end{array}$ & 2019 & - & $\begin{array}{l}\text { National sover- } \\
\text { eignty upholding } \\
\text { Transparency } \\
\text { Financial sus- } \\
\text { tainability } \\
\text { Engagement } \\
\text { with local eco- } \\
\text { nomic needs } \\
\text { Geopolitical } \\
\text { risks } \\
\text { Environmental } \\
\text { sustainability } \\
\text { Corruption } \\
\text { resistance }\end{array}$ & $\begin{array}{l}\text { Center for a } \\
\text { New American } \\
\text { Security (CNAS), } \\
\text { United States } \\
\text { (think tank) }\end{array}$ & Project & Checklist & $\begin{array}{l}10 \text { projects } \\
\text { from Latin } \\
\text { America, } \\
\text { Europe, } \\
\text { Africa, } \\
\text { Middle } \\
\text { East, South } \\
\text { and Cen- } \\
\text { tral Asia, } \\
\text { Southeast } \\
\text { Asia, and } \\
\text { Pacific } \\
\text { Islands }\end{array}$ & $\begin{array}{l}\text { Case } \\
\text { study }\end{array}$ \\
\hline $\begin{array}{l}\text { Five Con- } \\
\text { nectivity } \\
\text { Index }\end{array}$ & 2018 & _ & $\begin{array}{l}\text { Policy } \\
\text { coordination } \\
\text { Facilities } \\
\text { connectivity } \\
\text { Unimpeded } \\
\text { trade } \\
\text { Financial } \\
\text { integration } \\
\text { People-to- } \\
\text { people bond }\end{array}$ & $\begin{array}{l}\text { Peking Univer- } \\
\text { sity Regional } \\
\text { Studies Center }\end{array}$ & Country & & & \\
\hline
\end{tabular}


(cont.)

\begin{tabular}{|c|c|c|c|c|c|c|c|}
\hline Title & $\begin{array}{l}\text { Time } \\
\text { released }\end{array}$ & $\begin{array}{l}\text { What is the } \\
\text { evaluation about? }\end{array}$ & $\begin{array}{l}\text { Who are the } \\
\text { evaluators? }\end{array}$ & $\begin{array}{l}\text { What's the } \\
\text { level of } \\
\text { analysis? }\end{array}$ & $\begin{array}{l}\text { What } \\
\text { evalua- } \\
\text { tion tools } \\
\text { are pro- } \\
\text { posed? }\end{array}$ & $\begin{array}{l}\text { What is } \\
\text { the source } \\
\text { of data? }\end{array}$ & $\begin{array}{l}\text { What } \\
\text { analytical } \\
\text { methods } \\
\text { were } \\
\text { applied? }\end{array}$ \\
\hline $\begin{array}{l}\text { Energy } \\
\text { invest- } \\
\text { ment risk } \\
\text { assess- } \\
\text { ment }\end{array}$ & & $\begin{aligned} \text { - } & \text { Political and } \\
& \text { regulatory risk } \\
- & \text { Currency } \\
- & \text { Liquidity and } \\
& \text { refinancing risk } \\
- & \text { Resource risk }\end{aligned}$ & University & Country & $\begin{array}{l}\text { Simula- } \\
\text { tion and } \\
\text { modeling }\end{array}$ & $\begin{array}{l}\text { 5o coun- } \\
\text { tries in } \\
\text { BRI, IDRG, } \\
\text { World } \\
\text { Bank, EIA, } \\
\text { Statistical } \\
\text { Bulletin } \\
\text { of China's } \\
\text { Foreign } \\
\text { Direct } \\
\text { Invest- } \\
\text { ment, UN } \\
\text { Comtrade }\end{array}$ & $\begin{array}{l}\text { Fuzzy } \\
\text { integrated } \\
\text { evaluation } \\
\text { model } \\
\text { based on } \\
\text { entrophy } \\
\text { weight }\end{array}$ \\
\hline $\begin{array}{l}\text { Early stage } \\
\text { dynamic } \\
\text { quan- } \\
\text { titative } \\
\text { indicator } \\
\text { system } \\
\text { for BRI } \\
\text { project } \\
\text { evalua- } \\
\text { tion }\end{array}$ & 2018 & $\begin{aligned} &- \text { Investment } \\
& \text { risks } \\
&- \text { Culture and } \\
& \text { value } \\
& \text { dissemination } \\
&- \text { Shaping } \\
& \text { of China's } \\
& \text { overseas image } \\
&- \text { Social integra- } \\
& \text { tion and adapta- } \\
& \text { tion Social } \\
& \text { responsibility } \\
&-\quad \text { International tal- } \\
& \text { ent development }\end{aligned}$ & $\begin{array}{l}\text { Party School } \\
\text { of the CPC } \\
\text { Central } \\
\text { Committee, } \\
\text { China } \\
\text { (university) }\end{array}$ & Project & $\begin{array}{l}\text { Domain } \\
\text { and sub- } \\
\text { domain } \\
\text { indica- } \\
\text { tors }\end{array}$ & $\begin{array}{l}\text { Expert } \\
\text { rating } \\
\text { Examples } \\
\text { of BRI } \\
\text { projects } \\
\text { covering } 5 \\
\text { examples } \\
\text { of "hard } \\
\text { connectiv- } \\
\text { ity" and } 5 \\
\text { examples } \\
\text { of "soft } \\
\text { connectiv- } \\
\text { ity" }\end{array}$ & $\begin{array}{l}\text { Weighted } \\
\text { sum of } \\
\text { expert rat- } \\
\text { ing on key } \\
\text { indicators } \\
\text { Case } \\
\text { study }\end{array}$ \\
\hline
\end{tabular}

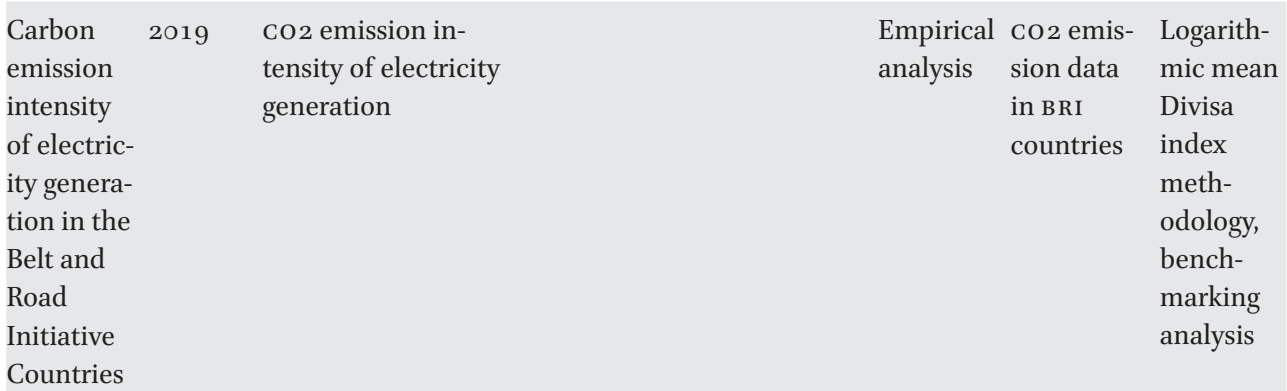


(cont.)

\begin{tabular}{|c|c|c|c|c|c|c|c|}
\hline Title & $\begin{array}{l}\text { Time } \\
\text { released }\end{array}$ & $\begin{array}{l}\text { What is the } \\
\text { evaluation about? }\end{array}$ & $\begin{array}{l}\text { Who are the } \\
\text { evaluators? }\end{array}$ & $\begin{array}{l}\text { What's the } \\
\text { level of } \\
\text { analysis? }\end{array}$ & $\begin{array}{l}\text { What } \\
\text { evalua- } \\
\text { tion tools } \\
\text { are pro- } \\
\text { posed? }\end{array}$ & $\begin{array}{l}\text { What is } \\
\text { the source } \\
\text { of data? }\end{array}$ & $\begin{array}{l}\text { What } \\
\text { analytical } \\
\text { methods } \\
\text { were } \\
\text { applied? }\end{array}$ \\
\hline $\begin{array}{l}\text { Regional } \\
\text { differ- } \\
\text { ences and } \\
\text { spatial } \\
\text { patterns } \\
\text { of health } \\
\text { status of } \\
\text { the mem- } \\
\text { ber states } \\
\text { in BRI }\end{array}$ & 2019 & $\begin{array}{l}\text { Health status } \\
-\quad \text { Life expectancy } \\
\text { at birth } \\
-\quad \text { Maternal } \\
\text { mortality rate } \\
-\quad \text { Total fertility } \\
\text { rate } \\
-\quad \text { HIV prevalence, } \\
\text { incidence rate; } \\
-\quad \text { Hepatitis B } \\
\text { surface antigen } \\
\text { prevalence rate } \\
-\quad \text { TB incidence } \\
\text { rate } \\
-\quad \text { Malaria parasite } \\
\text { prevalence rate } \\
\text { among children } \\
-\quad \text { Malaria inci- } \\
\text { dence rate } \\
-\quad \text { Cancer inci- } \\
\text { dence, by type of } \\
\text { cancer }\end{array}$ & $\begin{array}{l}\text { Ningxia } \\
\text { University, } \\
\text { Yinchuan } \\
\text { University, } \\
\text { Chinese } \\
\text { Academy of } \\
\text { Social Sciences } \\
\text { (university/ } \\
\text { think tank) }\end{array}$ & National & $\begin{array}{l}\text { List of } \\
\text { indica- } \\
\text { tors, } \\
\text { empirical } \\
\text { analysis }\end{array}$ & $\begin{array}{l}\text { Selected } \\
\text { statistical } \\
\text { data on } \\
\text { disease } \\
\text { and } \\
\text { socioeco- } \\
\text { nomics } \\
\text { in } 68 \text { BRI } \\
\text { countries } \\
\text { from } \\
2015 \\
\text { publica- } \\
\text { tion by } \\
\text { WB and } \\
\text { WHO }\end{array}$ & $\begin{array}{l}\text { Geo- } \\
\text { graphical } \\
\text { detector, } \\
\text { a novel } \\
\text { spatial } \\
\text { statistical } \\
\text { method }\end{array}$ \\
\hline
\end{tabular}

\begin{tabular}{|c|c|c|c|c|c|}
\hline $\begin{array}{l}\text { Economic } 2019 \\
\text { evaluation } \\
\text { of the Belt } \\
\text { and Road } \\
\text { Initiative } \\
\text { from an } \\
\text { unimped- } \\
\text { ed trade } \\
\text { perspec- } \\
\text { tive }\end{array}$ & $\begin{array}{l}\text { BRI project from } \\
\text { an unimpeded } \\
\text { trade perspective: } \\
\text { impact on GDP, } \\
\text { social welfare, } \\
\text { import, export, } \\
\text { trade pattern, } \\
\text { sectoral change, }\end{array}$ & $\begin{array}{l}\text { Anhui } \\
\text { University of } \\
\text { Finance and } \\
\text { Economics } \\
\text { (university) }\end{array}$ & $\begin{array}{l}\text { Country } \\
\text { Sector }\end{array}$ & $\begin{array}{l}\text { Empirical GTAP } \\
\text { analysis }\end{array}$ & $\begin{array}{l}\text { Simula- } \\
\text { tion }\end{array}$ \\
\hline
\end{tabular}


(cont.)

\begin{tabular}{|c|c|c|c|c|c|c|c|}
\hline Title & $\begin{array}{l}\text { Time } \\
\text { released }\end{array}$ & $\begin{array}{l}\text { What is the } \\
\text { evaluation about? }\end{array}$ & $\begin{array}{l}\text { Who are the } \\
\text { evaluators? }\end{array}$ & $\begin{array}{l}\text { What's the } \\
\text { level of } \\
\text { analysis? }\end{array}$ & $\begin{array}{l}\text { What } \\
\text { evalua- } \\
\text { tion tools } \\
\text { are pro- } \\
\text { posed? }\end{array}$ & $\begin{array}{l}\text { What is } \\
\text { the source } \\
\text { of data? }\end{array}$ & $\begin{array}{l}\text { What } \\
\text { analytical } \\
\text { methods } \\
\text { were } \\
\text { applied? }\end{array}$ \\
\hline $\begin{array}{l}\text { Impact of } \\
\text { financial } \\
\text { develop- } \\
\text { ment and } \\
\text { economic } \\
\text { growth on } \\
\text { environ- } \\
\text { mental } \\
\text { quality: an } \\
\text { empirical } \\
\text { analysis }\end{array}$ & 2019 & $\begin{array}{l}\mathrm{CO} 2 \text { emission } \\
\text { per capita }\end{array}$ & $\begin{array}{l}\text { Institute of } \\
\text { Technol- } \\
\text { ogy, Guangdong } \\
\text { University of } \\
\text { Foreign Studies } \\
\text { (university) }\end{array}$ & Country & $\begin{array}{l}\text { Empirical } \\
\text { analysis }\end{array}$ & $\begin{array}{l}\text { Data from } \\
\text { World De- } \\
\text { velopment } \\
\text { Indicators } \\
\text { (CO2 emis- } \\
\text { sion, GDP, } \\
\text { electricity } \\
\text { consump- } \\
\text { tion) }\end{array}$ & $\begin{array}{l}\text { Dynamic } \\
\text { seemingly } \\
\text { unrelated } \\
\text { regres- } \\
\text { sion; } \\
\text { Dumi- } \\
\text { trescu and } \\
\text { Hurlin } \\
\text { panel } \\
\text { causality } \\
\text { approach }\end{array}$ \\
\hline
\end{tabular}

countries

\begin{tabular}{|c|c|c|c|c|c|c|c|}
\hline $\begin{array}{l}\text { Govern- } \\
\text { ing local } \\
\text { sourcing } \\
\text { practices } \\
\text { of over- } \\
\text { seas proj- } \\
\text { ects for } \\
\text { the Belt } \\
\text { and Road } \\
\text { Initiative: } \\
\text { a frame- } \\
\text { work and } \\
\text { evaluation }\end{array}$ & 2019 & $\begin{array}{l}\text { Ex-post factors } \\
\text { of local sourcing } \\
\text { practices in overseas } \\
\text { infrastructure proj- } \\
\text { ects, including } 12 \\
\text { governance factors } \\
\text { in } 4 \text { dimensions } \\
\text { - Coordinated } \\
\text { adaptation } \\
\text { - Control and } \\
\text { - safeguarding } \\
\text { - Incentives and } \\
\text { payment struc- } \\
\text { ture } \\
- \text { Policies and } \\
\text { regulations }\end{array}$ & University & Factors & $\begin{array}{l}\text { Network } \\
\text { and rela- } \\
\text { tionship } \\
\text { analysis }\end{array}$ & $\begin{array}{l}\text { Expert } \\
\text { panel }\end{array}$ & $\begin{array}{l}\text { Fuzzy } \\
\text { Decision } \\
\text { Making } \\
\text { Trial and } \\
\text { Evalua- } \\
\text { tion Labo- } \\
\text { ratory } \\
\text { (DEMA- } \\
\text { TEL) } \\
\text { Relational } \\
\text { approach }\end{array}$ \\
\hline $\begin{array}{l}\text { China's } \\
\text { Belt and } \\
\text { Road } \\
\text { Initiative: } \\
\text { a pre- } \\
\text { liminary } \\
\text { quantita- } \\
\text { tive as- }\end{array}$ & 2018 & $\begin{array}{l}\text { Trade cost } \\
\text { reduction Energy } \\
\text { efficiency } \\
\text { improvement }\end{array}$ & $\begin{array}{l}\text { The Croesus } \\
\text { Group's Beijing } \\
\text { Office } \\
\text { (think tank / } \\
\text { consultancy) }\end{array}$ & Country & $\begin{array}{l}\text { Simula- } \\
\text { tion }\end{array}$ & $\begin{array}{l}\text { Invest- } \\
\text { ment, } \\
\text { infrastruc- } \\
\text { ture stock, } \\
\text { trade } \\
\text { cost from } \\
\text { various } \\
\text { sources }\end{array}$ & $\begin{array}{l}\text { Com- } \\
\text { putable } \\
\text { general } \\
\text { equilib- } \\
\text { rium }\end{array}$ \\
\hline
\end{tabular}


(cont.)

\begin{tabular}{|c|c|c|c|c|c|c|c|}
\hline Title & $\begin{array}{l}\text { Time } \\
\text { released }\end{array}$ & $\begin{array}{l}\text { What is the } \\
\text { evaluation about? }\end{array}$ & $\begin{array}{l}\text { Who are the } \\
\text { evaluators? }\end{array}$ & $\begin{array}{l}\text { What's the } \\
\text { level of } \\
\text { analysis? }\end{array}$ & $\begin{array}{l}\text { What } \\
\text { evalua- } \\
\text { tion tools } \\
\text { are pro- } \\
\text { posed? }\end{array}$ & $\begin{array}{l}\text { What is } \\
\text { the source } \\
\text { of data? }\end{array}$ & $\begin{array}{l}\text { What } \\
\text { analytical } \\
\text { methods } \\
\text { were } \\
\text { applied? }\end{array}$ \\
\hline $\begin{array}{l}\text { Under- } \\
\text { standing } \\
\text { China's } \\
\text { Belt and } \\
\text { Road } \\
\text { Initiative: } \\
\text { motiva- } \\
\text { tion, } \\
\text { frame- } \\
\text { work and } \\
\text { assess- } \\
\text { ment }\end{array}$ & 2016 & $\begin{array}{l}\text { Assessment frame- } \\
\text { work based on the } \\
\text { five pillars of BRI: } \\
\text { - } \text { Policy dialogue } \\
\text { - } \text { Infrastructure } \\
\text { connectivity } \\
\text { - Unimpeded } \\
\text { trade } \\
\text { - Financial sup- } \\
\text { port } \\
\text { - People-to-people } \\
\text { exchange } \\
\text { Risks associated } \\
\text { with BRI } \\
\text { - Coordination } \\
\text { mechanism } \\
\text { - Clash of political } \\
\text { values } \\
\text { - China's export of } \\
\text { excess capacity } \\
\text { and its conse- } \\
\text { quences } \\
\text { - Financial } \\
\text { sustainability of } \\
\text { cross-country } \\
\text { projects }\end{array}$ & $\begin{array}{l}\text { China Party } \\
\text { School (think } \\
\text { tank/university) }\end{array}$ & Initiative & $\begin{array}{l}\text { Descrip- } \\
\text { tive }\end{array}$ & $\begin{array}{l}\text { BRI policy } \\
\text { documents }\end{array}$ & $\begin{array}{l}\text { Descrip- } \\
\text { tive }\end{array}$ \\
\hline
\end{tabular}




\section{References}

Africa Waste and Environment Management Centre (AWEMC). (2012). Environmental and Social Impact Assessment Study Report for the Proposed Mombasa-Nairobi Standard Gauge Railway Project. AWEмc: Nairobi. Retrieved from https://africog .org/wp-content/uploads/2017/o6/SGR-EAS-Impact-report.pdf.

African Development Bank. (2011). Infrastructure Outlook 2040: Programme for Infrastructure Development in Africa. Retrieved from https://afdb-org.jp/wp-content/ uploads/2016/o1/PIDA_EN_140523_ONRI-Rapport.pdf.

Ascensao, F., Fahrig, L., Clevenger, A. P., Corlett, R. T., Jaeger, J. A. G., Laurance, W. F., \& Pereira, H. M. (2018). Environmental challenges for the Belt and Road Initiative. Nature Sustainability, 1(5), 206-209. doi:10.1038/s41893-018-0059-3.

Asian Society. (2019). Navigating the Belt and Road Initiative. Report, Retrieved from https://asiasociety.org/sites/default/files/2019-o6/Navigating\%2othe\%2oBelt\%2O and\%2oRoad\%2oInitiative_2.pdf.

в вс. (2017, June 8). Will Kenya get value for money from its new railway? вв С, Retrieved from https://www.bbc.com/news/world-africa-40171095.

Business and Human Rights Resource Center. (2016). Kenya. Govt. agency attributes high HIV/AIDS to ongoing road \& railway construction. Retrieved from https://www .business-humanrights.org/en/kenya-govt-agency-attributes-high-hivaids-to -ongoing-road-railway-construction.

Business Daily (2018, July 2). Sh534bn China debt now 72pc of bilateral loans pile. Business Daily, Retrieved from https://www.businessdailyafrica.com/economy/ Sh534bn-China-debt-now-72pc-of-bilateral-loans-pile/3946234-4642122-743gtxz/ index.html.

Chen, J., Bergquist, R., Zhou, X. N., Xue, J. B., \& Qian, M. B. (2019). Combating infectious disease epidemics through China's Belt and Road Initiative. Plos Neglected Tropical Diseases, 13(4), e0007107. doi: o.1371/journal.pntd.0007107.

China News (2018, August 15). Belt and Road Early Stage Project Dynamic Assessment Report Release. Chine News, Retrieved from https://www.chinanews.com/gn/2018/ o1-15/8424656.shtml.

CNAS. (2019). Grading China's Belt and Road. Retrieved from https://www.cnas.org/ publications/reports/beltandroad.

Council of Foreign Relations. (2019). China's Massive Belt and Road Initiative. Retrieved from https://www.cfr.org/backgrounder/chinas-massive-belt-and-road-initiative.

CRBC. (2016). China Road and Bridge Corporation Social Responsibility Report 2015 on Mombasa Nairobi SGR Project. n.l. CRBC.

CRBC. (2018). China Road and Bridge Corporation Social Responsibility Report 2016 on Mombasa Nairobi SGR Project. n.l. CRBC. 
CRBC. (2019). China Road and Bridge Corporation Social Responsibility Report 2017-18 on Mombasa Nairobi SGR Project. n.l. CRBC.

Daily Nations. (2018, November 25). Seven officials held as detectives probe SGR tickets scandal. Daily Nations, Retrieved from https:/www.nation.co.ke/news/Seve n-officials-held-as-detectives-probe-SGR-tickets-scandal/1056-486758o-ftcfnsz/ index.html.

Daily Nations. (2019, May 29). Excessive borrowing is hurting economy. Daily Nations, https://www.nation.co.ke/oped/editorial/Excessive-borrowing-is-hurting-eco nomy/440804-5135856-m3ompmz/index.html.

Dong, L., Yang, X. H., \& Li, H. T. (2018). The Belt and Road Initiative and the 2030 Agenda for Sustainable Development: seeking linkages for global environmental governance. Chinese Journal of Population Resources and Environment, 16(3), 203-210. doi:10.108o/10042857.2018.1487745.

Dossani, R., Bouey, J., \& Zhu, K. (2019). Developmental Impacts of the BRI in the Asia-Pacific. Working Paper, RAND Center for Asia Pacific Policy.

Dossani, R., Bouey, J. and Zhu, K. (2020). Demystifying the Belt and Road Initiative; A Clarification of its Key Features, Objectives and Impacts. RAND Corporation. Retrieved from https://www.rand.org/pubs/working_papers/WR1338.html.

Duflo, E., \& Pande, R. (2005). Dams. Working Papers 923, Economic Growth Center, Yale University.

Fahri, J., Biesenthal, C., Pollack, J., Sankaran, S. (2002). Understanding megaproject success beyond the project close-out stage. Construction Economics and Building, 15(3), 48-58. doi:10.5130/AJCEB.v15i3.4611.

FOCAC, 2017. https://www.focac.org/chn/zfgx/jmhz/t1471951.htm.

FOCAC, 2019. https://www.focac.org/chn/zfgx/jmhz/t1626532.htm.

FOCAC, 2019. https://www.focac.org/chn/zfgx/jmhz/t1669o34.htm.

FOCAC, 2019. https://www.focac.org/chn/zfgx/jmhz/t1669o34.htm.

Hu, Y., Chan, A. P. C., Le, Y., Xu, Y. \& Shan, M. (2015). Developing a program organization performance index for delivering construction megaprojects in China: Fuzzy synthetic evaluation analysis. Journal of Management in Engineering, 32(4). doi:10.1061/ (ASCE)ME.1943-5479.0000432.

Huaxia. (2O2O, July 7). Kenya SG R operator says railway contributes to mitigating spread of COVID-19. Xinhua, Retrieved from http://www.xinhuanet.com/english/202O07/07/c_139194938.htm.

Institute of Chinese Studies (ISC). (2019). China's Infrastructure Development in Africa: An Examination of Projects and Tanzania and Kenya. Retrieved from https://www .icsin.org/uploads/2019/12/11/c924317a941e3d430o99f6f7d652abf2.pdf. 
Kembayev, Z. (2019). The emerging Eurasian common energy market: What is its potential impact on China's Belt and Road Initiative? Journal of World Investment \& Trade, 2o(2-3), 401-424. doi:10.1163/221190oo-12340137.

Kenya China Economic and Trade Association and Embassy of the People's Republic of China in the Republic of Kenya. (2019). Chinese Enterprises in Kenya Social Responsibility Report 2018-2019. Nairobi.

Kilman, D., Rush, D., Lee, K., \& Cooper, Z. (2019). Grading China's Belt and Road. Center for A New American Security.

Lehtonen, M. (2014). Evaluating megaprojects: From the 'iron triangle' to network mapping. Evaluation, 2o(3), 278-295. doi:10.1177/1356389014539868.

Lehtonen, M., Joly, P., \& Aparico, L. (Eds.). (1991). Socioeconomic Evaluation of Megaprojects: Dealing with Uncertainties. Routledge.

Li, H. X., Huang, Y. X., \& Tian, S. C. (2019). Risk probability predictions for coal enterprise infrastructure projects in countries along the Belt and Road Initiative. International Journal of Industrial Ergonomics, 69, 110-117. doi:10.1016/j.ergon.2018.10.0o6.

Li, J., Xui, F. J., Sun, Z. J., \& Wang, J. F. (2019). Regional differences and spatial patterns of health status of the member states in the "Belt and Road" Initiative. Plos One, 14(1), eo211264. doi:10.1371/journal.pone.0211264.

Li, Y., \& Taube, M. (2018). The implications of the 'Belt and Road Initiative' on globalization and inclusive growth for the Eurasian continent. Journal of Chinese Economic and Business Studies, 16(3), 233-240. doi:10.1080/14765284.2018.1491667.

Lu, H., Rohr, C., Hafner, R., \& Knack, A. (2018). China Belt and Road Initiative: Measuring the Impact of Improving Transportation Connectivity on Trade in the Region. RAND.

Macaes, B. (2019). Belt and Road: A Chinese World Order. Hurst \& Company.

McDavid, J. C., Huse, I., \& Hawthorn, L. R. L. (2019). Program Evaluation and Performance Measurement: An Introduction to Practice, 3rd Edition. Sage Publishing.

Merrow, E. W. (2011). Industrial Megaprojects: Concepts, Strategies, and Practices for Success. Wiley.

Ministry of Commerce (моғсом). (2017). The Belt and Road Initiative Selection of Early Achievements. Xinhua Publishing.

Ministry of Transport, Infrastructure, Housing, and Urban Development. (2017). Environmental and Social Assessment Project Report (ESIA).

National Development and Reform Commission (NDRC), Ministry of Commerce (моғсом) and Ministry of Foreign Affairs (MFA). (2017). Building the Belt and Road: Concept, Practice and China's Contribution. NDRC, MOFCOM and MFA.

National Development and Reform Commission (NDRC), Ministry of Commerce (моғсом) and Ministry of Foreign Affairs (MFA). (2015). Belt and Road: Vision and Action. NDRC, MOFCOM and MFA. 
Ndiho Media. (2018, August 17). Environmental Costs Of China-Kenya's New Standard Gauge Railway. Retrieved from https://paulndiho.com/2018/o8/17/environmental -costs-of-china-kenyas-new-standard-gauge-railway/.

Olingo, A. (2019, June 11). After S GR, Kenya's next Shyoobn debt trap for power project. Daily Nations, Retrieved from https:/www.nation.co.ke/news/After-SGR--Kenya-s -next-Sh9oobn-debt-trap-/1056-5152386-1hbg2r/index.html.

Quartz Africa. (2018, October 7). China now owns more than 70\% of Kenya's bilateral debt. Retrieved from https://qz.com/africa/1324618/china-is-kenyas-largest-creditor -with-72-of-total-bilateral-debt/.

Reuters. (2018, January 8). Kenya Arrests Two Top Officials Suspected for Corruption over 3-Billion Railway. Retrieved from https://www.reuters.com/article/us-kenya -corruption-railway/kenya-arrests-two-top-officials-for-suspected-corruption-over -new-3-billion-railway-idUSKBN1KWo7L.

Rolland, N. (2017). China's Eurasian Century: Political and Strategic Implications of the Belt and Road Initiative. The National Bureau of Asian Research.

Rossi, P. H., Lipsey, M. W., \& Henry, G. T. (2019). Evaluation: A Systematic Approach, 8th Edition. Sage.

Rupa, M. (2019). BRI Economics: Opportunities and Risks of Transport Corridor. World Bank.

Saud, S., Chen, S. S., Danish, \& Haseeb, A. (2019). Impact of financial development and economic growth on environmental quality: an empirical analysis from Belt and Road Initiative (BRI) countries. Environmental Science and Pollution Research, 26(3), 2253-2269. doi:10.1007/s11356-018-3688-1.

Scobell, A., Lin, B., Shatz, H. J., Johnson, M., Hanauer, L, \& Chase, M. S. (2018). At the Dawn of Belt and Road: China in the Developing World. RAND.

Silver, H. (2015) The Contexts of Social Inclusion. United Nations Department of Economic and Social Affairs Working Paper no. 144.

Teo, H. C., Lechner, A. M., Walton, G. W., Chan, F. K. S., Cheshmehzangi, A., Tan-Mullins, M., Chan, H. K., Sternberg, T., \& Campos-Arceiz, A. (2019). Environmental impacts of infrastructure development under the Belt and Road Initiative. Environments, 6(6), 72. doi:10.339o/environments6o6oo72.

The Star. (2019, January 5). "New HIV infections double along SGR counties - report", The Star, Retrieved from https://www.the-star.co.ke/news/2019-05-o1-new-hiv -infections-double-along-sgr-counties-report/.

The Star. (2019, May 30). Kenya's debt to GDP ratio shrinks marginally - IMF report. The Star, Retrieved from https://www.the-star.co.ke/business/2019-05-3o-kenyas -debt-to-gdp-ratio-shrinks-marginally-imf-report/. 
UNCTAD \& World Bank. (2018). Environmental and Social Impact Assessments. Responsible Agricultural Investment (RAI) Knowledge Into Action Note, no. 14. World Bank.

Wang, J. J., \& Yau, S. (2018). Case studies on transport infrastructure projects in belt and road initiative: An actor network theory perspective. Journal of Transport Geography, 71, 213-223. doi:10.1016/j.jtrangeo.2018.01.007.

Wang, S., Song, J. N., Wang, X. E., \& Yang, W. (2019). The spatial and temporal research on the coupling and coordinated relationship between social economy and energy environment in the Belt and Road Initiatives. Sustainability, 11(2), 407. doi:10.339o/ su11020407.

Wang, Y., \& Wissenbach, U. (2019). Clientelism at work? A case study of Kenyan Standard Gauge Railway project. Economic History of Developing Regions, 34(3), 28o-299. doi:10.108o/20780389.2019.1678026.

Wong, A. (2019). China's economic statecraft under Xi Jinping, Retrieved from https:// www.brookings.edu/articles/chinas-economic-statecraft-under-xi-jinping/.

World Bank Blog. (2011). Strategies for Evaluating the impact of Big Infrastructure Projects: How Can we tell if One Big Thing Works? Retrieved from https://blogs .worldbank.org/impactevaluations/strategies-for-evaluating-the-impact-of-big -infrastructure-projects-how-can-we-tell-if-one-big-thing.

World Bank. (2019). Belt and Road Economics: Opportunities and Risks of Transport Corridors. World Bank.

Zhu, C. Z., \& Gao, D. W. (2019). A research on the factors influencing Carbon emission of transportation industry in "the Belt and Road Initiative" countries based on panel data. Energies, 12(12), 2405. doi:10.339o/en12122405. 